Annuaire suisse de politique de développement

8 | 1988

Annuaire Suisse - Tiers Monde 1989

\title{
Pour la promotion des femmes dans les pays du Sahel
}

Frauenfördernde Massnahmen in den Sahelländern

\section{Marie-Thérèse Roggo}

\section{OpenEdition}

1 Journals

Édition électronique

URL : http://journals.openedition.org/aspd/1293

DOI : $10.4000 /$ aspd. 1293

ISSN : 1663-9669

Éditeur

Institut de hautes études internationales et du développement

\section{Édition imprimée}

Date de publication : 1 décembre 1988

Pagination : 183-192

ISSN : 1660-5934

\section{Référence électronique}

Marie-Thérèse Roggo, «Pour la promotion des femmes dans les pays du Sahel », Annuaire suisse de politique de développement [En ligne], 8| 1988, mis en ligne le 13 mars 2013, consulté le 08 septembre 2020. URL : http://journals.openedition.org/aspd/1293 ; DOI : https://doi.org/10.4000/aspd. 1293

Ce document a été généré automatiquement le 8 septembre 2020.

(C) The Graduate Institute / Geneva 


\section{Pour la promotion des femmes dans les pays du Sahel}

Frauenfördernde Massnahmen in den Sahelländern

Marie-Thérèse Roggo

\section{NOTE DE L'ÉDITEUR}

En français, résumé seulement. Lire l'article original en allemand dans Schweizerisches Jahrbuch für Entwicklungspolitik : « Frauenfördernde Massnahmen in den Sahelländern ", http://sjep.revues.org/1093. 